\section{Patrick Gerard Beirne}

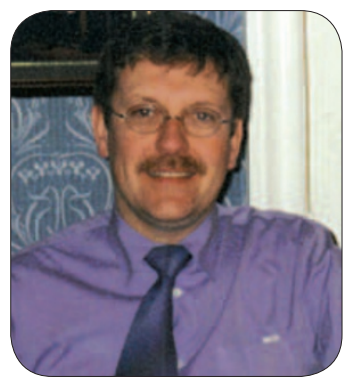

Pat was born in Belfast on 17 September 1955, the youngest of six children. He left his native city only once for a period of seven years to be educated by the Vincentian Priests at St. Patrick's College, Armagh. He returned to Belfast in 1974 to study dentistry at Queen's University of Belfast. He followed in the footsteps of his eldest brother, Laurence (RIP), then renowned for his work in restorative dentistry at the School of Dentistry, Queen's University of Belfast. Laurence was an exemplary role model.

Pat made many friends during his time in the School of Dentistry - all envied this close-knit community. He was a good student and graduated in 1980. He was awarded the John Clarke Prize, attaining first place in prosthetic dentistry.

Pat spent some years working with senior colleagues in general practice gaining valuable experience, before opening his own dental surgery in Belfast in 1985. He may be the only dental practitioner, well-acquainted with DIY around his own home, who planned and fitted the dental units and fixtures in his dental surgery.

\section{John Maxwell Fairley}

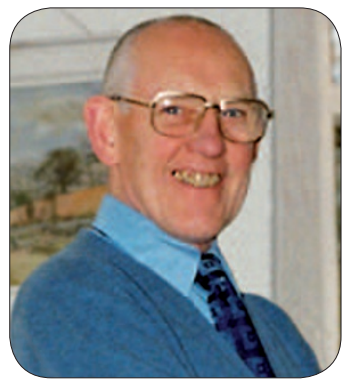

John Maxwell Fairley died on 7 April 2007 aged 91 years.

He was born and brought up in Dundee, where he attended the Morgan Academy. After leaving school he worked in insurance before studying dentistry at the University of St Andrews. He qualified LDS in 1941 and, while working as house officer/demonstrator at Dundee Dental Hospital, he studied for the degree of BDS (then a higher qualification). He graduated BDS with distinction in 1942.

John joined the RAF in 1943 and was posted to India serving in a field hospital as dental officer and, as required, maxillofacial surgeon.

On demobilisation in 1945, he was appointed senior lecturer in the University of St Andrews and head of Conservative Dentistry at the Dundee Dental School and Hospital. When this establishment underwent major expansion in the 1960s John was heavily involved in the planning and design of the clinical equipment. When, in 1977, Conservative Dentistry became an autonomous department in the University of Dundee, he was appointed as its first head - a position that he held until retirement in 1980.

Known to numerous generations of dental students as 'John F', he had a uniquely down-to-earth style of teaching in which he strove to simplify and demystify the intricacies of diagnosis and

\section{He may be the only dentist who planned and fitted the dental units and fixtures in his dental surgery.}

He was a very successful practitioner, supported by a loyal staff. He loved people and had time for everyone. He wanted the highest standard of care for his patients. He opened his surgery out-of-hours on many occasions to help a sufferer. He attended several immobile patients in their homes providing much needed treatments - his domiciliary bag was cleverly equipped with a craft drill.

Pat married in 1981. Sadly, his successful career was brought to a premature end in 2000 when he lost his battle with multiple sclerosis. He was a family man who knew the importance of time spent together with family and enjoyed many holidays in Donegal, where he died on 29 July 2006. He leaves his wife, two sons and two daughters. One of his daughters is following in his footsteps and is presently a student in the School of Dentistry, Queen's University of Belfast.

Patricia Beirne

\section{He had a uniquely down-to-earth style of teaching...}

operative technique. He was a highly skilled clinician and demanded high standards from students. He could, on occasion, be blunt in his criticism, dismissing, for example, a poorly formed ceramic crown with the comment, 'That's just a lump'! Some considered that he was slow to praise. Perhaps so; but praise from John Fairley was praise indeed.

With his jaunty style and fund of stories from wartime and other experiences, he was undoubtedly a 'character'. His many interests included gardening - especially rose growing and, during the summer, he would sport a specimen rose in his buttonhole, kept fresh with its stem in a discarded local anaesthetic cartridge filled with water hidden discreetly behind the lapel of his jacket!

Those of us privileged to teach in Conservative Dentistry with John and who were frequently most royally entertained in his home by him and his wife, Ivy, whom he married during the war, will long retain the happiest memories of him and of his wise counsel.

Their younger son, David, having predeceased him, he is survived by Ivy and their older son, John, to whom deepest sympathy is extended.

A. R. G. 